\title{
ПРОЦЕСИ ЦИФРОВІЗАЦІї ЯК НЕВІД'ЄМНА СКЛАДОВА СУЧАСНОГО БАНКІВСЬКОГО МЕНЕДЖМЕНТУ
}

\section{DIGITALIZATION PROCESSES AS AN INTEGRAL COMPONENT OF MODERN BANKING MANAGEMENT}

\author{
Касич Алла Олександрівна \\ доктор економічних наук, профресор, \\ Київський національний університет технологій та дизайну \\ ORCID: https://orcid.org/0000-0001-7019-1541 \\ Наумкіна Іліна Олегівна \\ студентка, \\ Київський національний університет технологій та дизайну \\ ORCID: https://orcid.org/0000-0003-2229-1307 \\ Kasych Alla, Naumkina Ilina \\ Kyiv National University of Technologies and Design
}

\begin{abstract}
Стаття присвячена дослідженню теоретичних положень та обґрунтуванню практичних рекомендацій щодо удосконалення процесів цифровізації в банківській діяльності на практику українських банків. Розвиток цифрової економіки є важливим етапом розбудови в Україні цифрового ринку та його подальшої інтеграції до єдиного глобального цифрового ринку. Проаналізовано основні характеристики цифрової економіки, чинники, стан, а також систематизовано основні проблемні питання поточного етапу розвитку банків. Досліджено фрункціонування та темпи діджиталізації українських банків АТ КБ «ПриватБанк» та АТ «Універсал Банк». Розроблено рекомендації щодо підвищення рівня цифровізації банків, а також методичні положення щодо удосконалення системи управління процесами цифровізації діяльності українських банків.
\end{abstract}

Ключові слова: цифрова економіка, цифровізація, банки, банківська діяльність, управління, цифровий банкінг, інноваційна діяльність.

Статья посвящена исследованию теоретических положений и обоснованию практических рекомендаций по усовершенствованию процессов циоровизации в банковской деятельности на практику украинских банков. Развитие цифровой экономики является важным этапом продвижения в Украине цифрового рынка и его дальнейшей интеграции к единственному глобальному цифровому рынку. Проанализированы основные характеристики цифрровой экономики, фракторы, состояние, а также систематизированы основные проблемные вопросы текущего этапа развития банков. Исследованы функционирование и темпы диджитализации украинских банков АО КБ «ПриватБанк» и АО «Универсал Банк». Разработаны рекомендации по повышению уровня цифрровизации банков, а также методические положения по усовершенствованию системы управления процессами цифровизации деятельности украинских банков.

Ключевые слова: цифровая экономика, цифровизация, банки, банковская деятельность, управление, цифровой банкинг, инновационная деятельность.

The article is devoted to the study of theoretical provisions and substantiation of practical recommendations for improving digitalization processes in banking to the practice of Ukrainian banks. In the development of information society and globalization, the urgency of studying digitalization processes is an integral part of modern management. It is digital innovations that are based on the use of a qualitatively new type of information and telecommunication technologies that become the productive basis for the development of various sectors of the economy, including the banking sector. The story of the digital economy is a prerequisite for the development of the digital market in Ukraine and its further integration into the single global digital market. The need for digitalization is due to the desire to improve processes constantly, and on the part of banks - to improve their competitive position in the market, which has a positive impact on the country's economy and its investment attractiveness. But at the same time, a significant number of problems regarding the vision of the concept of digitalization of the economy and the directions of its development remain insufficiently solved. That is why the urgency of the digital economy in Ukraine is associated with the need to use in business, management, and public life of the latest electronic technologies, services, infor- 
matization of production processes, improving digital skills and competencies of the population. The purpose of the article is to substantiate the areas of improvement of the management system of banks' digitalization processes to increase their efficiency. In the process of writing, the paper used the following general scientific methods: induction and deduction (in the formation of theoretical and methodological foundations of the digital economy); analysis and synthesis (during the study of banks JSC CB "PrivatBank" and JSC "Universal Bank"). The characteristics of the digital economy, factors, state, and the main problematic issues of the current stage of development of banks are analyzed. The functioning and rates of digitalization of Ukrainian banks of JSC CB "PrivatBank" and JSC "Universal Bank" are studied. The paper has recommendations for increasing the level of digitalization of banks and methodological provisions for improving the management in Ukrainian banks.

Keywords: digital economy, digitalization, banks, banking activity, management, digital banking, innovation activities.

Постановка проблеми. В умовах розвитку інсрормаційного суспільства і глобалізації актуальність вивчення процесів цисрровізації $€$ важливою частиною сучасного менеджменту. Саме цисррові інновації, які базуються на використанні якісно нового типу інфрормаційнотелекомунікаційних технологій, стають продуктивним підґрунтям розвитку різних секторів економіки, в тому числі банківського сектора.

Аналіз останніх досліджень і публікацій. Проблемі розвитку цисрової економіки та бізнес-процесам, що відбуваються в суспільстві під впливом цифровізації, значну увагу приділяли вітчизняні та зарубіжні вчені, зокрема: В.В. Апалькова, Н.Е. Дєєва, А.П. Добринін, С.М. Веретенюк, Г.Т. Карчева, В.С. Куйбіда, С.В. Коляденко, Н.М. Краус, Д. Лайон, В.І. Ляшенко та ін. Загальні питання управління цисрровою економікою, а також їі розвитком знайшли широке відображення в роботах В.Л. Диканя, С.В. Панченко, І.В. Воловельської, О.В. Шраменко, Ю.М. Уткіної.

Виділення невирішених раніше частин загальної проблеми. Значна кількість проблем щодо бачення концепції цифрровізації економіки та напрямів її розвитку залишаються недостатньо розкритими. У наявних наукових доробках неповною мірою знайшли відображення сучасні погляди науковців щодо цифрової економіки. До того ж, враховуючи випереджальні тенденції прикладної площини розвитку цифровізації економічних процесів, назрілим сьогодні $€$ аналіз напрацювань практиків.

Формулювання цілей статті (постановка завдання). Ключові завдання стосуються дослідження теоретичних основ управління процесами цифровізації в банківській діяльності шляхом аналізу публікацій науковців та практиків, дослідження ефрективності срункціонування українських та закордонних банків в умовах розвитку цифррової економіки та обґрунтування на цій основі заходів 3 активізації інноваційного розвитку за рахунок подальшої цифровізації.

\section{Виклад основного матеріалу дослід-} ження. Необхідність у цифровізації зумовлюється прагненням до постійного удосконалення процесів, а з боку компаній покращення власного конкурентного становища на ринку, що в свою чергу позитивно впливає на економіку країни та її інвестиційну привабливість. У цифрровому світі виграють ті компанії, які мають змогу запропонувати таку цінність, яка б повною мірою задовольняла попит споживача [7].

Циоровізація економіки - це інноватизація економічного розвитку за рахунок імплементації циоррових ресурсів у всі сорери життедіяльності суспільства: виробництво та споживання товарів та послуг, сфреру багаторівневого управління тощо. На даному етапі розвитку суспільства можливо встановити, що сьогоднішній економічний напрям - це неоекономіка, що, зароджується за визначенням [2, с. 18], трактується як постіндустріальна стадія розвитку економічної системи, фрундаментальними теоретичними конструкціями якої $€$ інфрормаційна, інноваційна, цифрова та мережева економіки. Розмежування цих концепцій ґрунтується на виділенні ключових сорер та ресурсів економічного розвитку.

Ядром цифрової економіки та головним чинником зростання України визначено цифрровізацію бізнесу та бізнес-процесів в цілому. Перетворююча сила цисрових технологій дозволяє змінити традиційні моделі бізнесу, виробничі ланцюги та обумовлює появу нових продуктів та інновацій. Цифровізація виводить на новий рівень соеру виробництва, примушуючи компанії ставити цифрову трансформацію основною задачею стратегії розвитку.

Циоррова трансорормація - це впровадження сучасних технологій в бізнес-процеси компанії. Цей підхід має на увазі не лише установку сучасного устаткування або програмного забезпечення, але і фрундаментальні зміни в підходах до управління, корпоративної культури, зовнішніх комунікаціях. 
В результаті підвищуються продуктивність кожного співробітника і рівень задоволеності клієнтів, а компанія отримує репутацію прогресивної і сучасної.

У банківському секторі особливості цифррової транссрормації аналізує Л. Кузнєцова, яка виокремлює п'ять основних етапів розвитку: 1) поява Digital-каналів; 2) створення і впровадження Digital-продуктів; 3) зміна бізнесмоделей банків; 4) створення штучного інтелекту; 5) побудова цифррового ДНК [6].

Сучасні банки фрункціонують у ситуації стрімких і незворотних змін у технологіях, конкуренції на ринку банківських послуг зі збільшенням кількості небанківських організацій, змін у поведінці клієнтів і регулюванні. У результаті банки та їхні операційні моделі, що фрункціонують нині, не зможуть залишатися незмінними в майбутньому. Взаємозв'язок процесів цифрровізації та інноватизації в рамках трансформаційних перетворень банківського сектору представлено на рисунку 1.

Процеси розвитку та перетворення економіки в цифрову відбувається під впливом багатьох чинників. Винятково важливу роль у сприянні розвитку цисрровізації відіграють 7 основних чинників (табл. 1).

Сучасний світовий банківський сектор під впливом цифрровізації зазнає радикальних змін: клієнти використовують все більше каналів отримання банківських послуг, користуючись новими платфрормами для взаємодії з банками, тому в результаті цисрровізації банківських процесів покращується клієнтський досвід. Пандемія та карантинні обмеження пришвидшили зміни в платіжних звичках громадян у бік безготівкових розрахунків, зокрема в Інтернеті. Українці активніше переходять на безготівкові платежі та частіше користуються послугами електронної комерції.

Водночас зберігається тренд зростання популярності безконтактних платіжних інструментів та розрахунків з ними. Банківський сектор України поступово освоює цифррові технології, а це приводить до того, що моделі обслуговування значно змінюються. Поява «необанків» як нової фрорми банківської діяльності пов'язана із значним розвитком Інтернет-технологій та появою нового покоління споживачів, які активно використовують смартфрони у повсякденному житті та віддають перевагу тотальному дистанційному контролю власними фрінансами. Інтернет-банкінг завоював значну частку ринку, оскільки пропонує своїм клієнтам цінніші переваги, ніж традиційні банки: від знижених комісій до можливості відкриття та ведення рахунків без відвідування відділення банку.

Сьогодні стан діджитал-трансорормацій на підприємствах можна охарактеризувати так [13]: понад 60\% компаній уже використовують діджитал-технології під потреби клієнта; до 20\% тільки починають знайомитися 3 діджитал та роблять перші кроки по впровадженню; близько 15\% компаній залучають і обслуговують клієнтів за допомогою цисррових технологій; лише 3-4\% компаній повністю діджиталізовані.

Враховуючи присутність державних інститутів у процесі фоомування економічних стосунків суб'єктів цифрової економіки, мають застосовуватися принципи, які ґрунтуються на міжнародних правових нормах та стандартах регіонів із захисту прав людини, поточній практиці окремих держав, а також на загальних принципах права, визнаних міжнародним товариством.

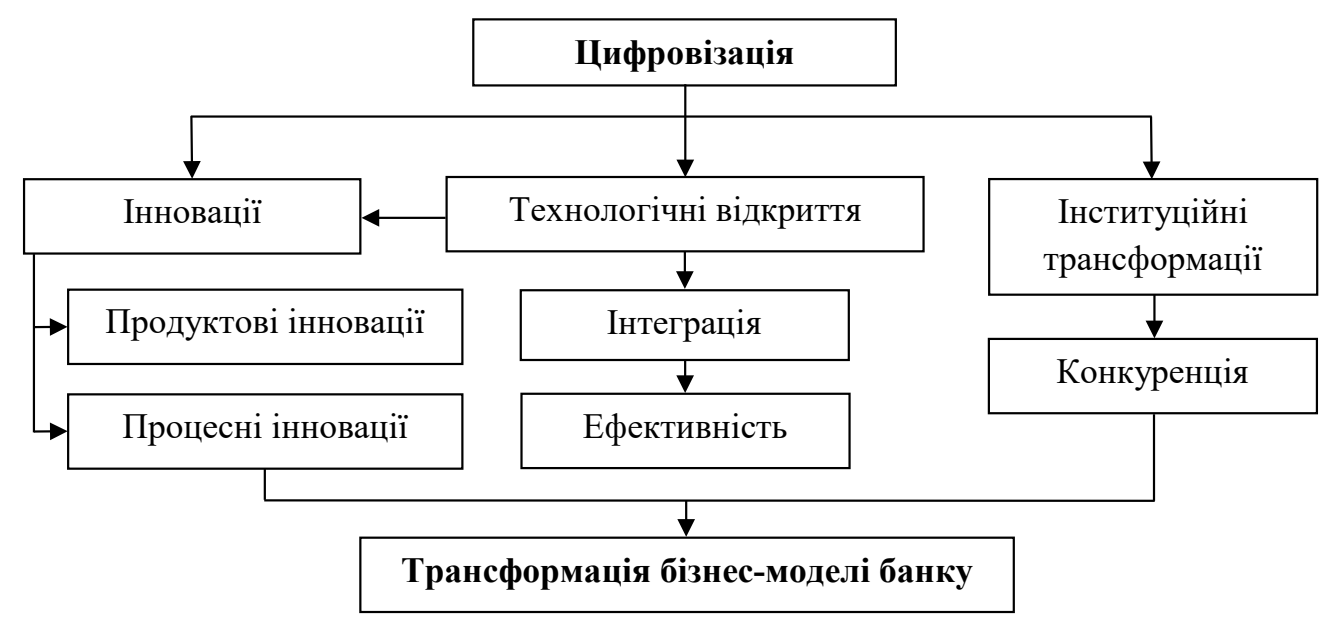

Рис. 1. Інноватизація діяльності банку в умовах цифрової економіки Джерело: розроблено авторами на основі [2] 
Таблиця 1

Чинники розвитку цифрової економіки

\begin{tabular}{|c|c|}
\hline Чинник & Вплив \\
\hline COVID-19 & $\begin{array}{l}\text { Хоча пандемія згубно впливає на людський розвиток загалом, } \\
\text { вона прискорила цифровізацію. Більшість населення по всьому } \\
\text { світу було змушене працювати віддалено, і більшість інструментів, } \\
\text { необхідних для роботи, вже були створені. }\end{array}$ \\
\hline Цифррові фрінанси & $\begin{array}{l}\text { Упровадження цифрових технологій у банківський сектор } \\
\text { економіки, онлайн платежі в електронній торгівлі, електронні } \\
\text { перекази, електронні торги, електронні державні закупівлі, } \\
\text { електронний державний бюджет, державні соціальні допомоги, } \\
\text { мобільні гроші, цифрова валюта тощо. }\end{array}$ \\
\hline Соціальні мережі & $\begin{array}{l}\text { Вигідна з економічної точки зору взаємодія, є джерелом } \\
\text { інноваційних ідей та базою для збирання та розповсюдження } \\
\text { інфрормації, сприяє залученню учасників в політичне життя та } \\
\text { соціальним змінам. }\end{array}$ \\
\hline Цифррова ідентифрікація & $\begin{array}{l}\text { Застосування єдиної електронної системи засвідчення особистості } \\
\text { для безпечних банківських операцій, голосування, доступ до } \\
\text { соціальних послуг, оплата комунальних платежів та інше. } \\
\end{array}$ \\
\hline Революція даних & $\begin{array}{l}\text { У фоокусі уваги перебувають взаємопов'язані інновації - великі } \\
\text { дані і відкриття даних. При цьому аналітика великих масивів } \\
\text { даних застосовується для вдосконалення транспортних потоків, } \\
\text { оцінки узагальнених макроекономічних показників, удосконалення } \\
\text { управлінських процесів. }\end{array}$ \\
\hline $\begin{array}{l}\text { Покращення } \\
\text { конкурентного } \\
\text { становища }\end{array}$ & $\begin{array}{l}\text { За відсутності проведення адекватної та своєчасної оцінки рівня } \\
\text { власного конкурентного потенціалу, виявлення й аналізу фракторів } \\
\text { безпосереднього впливу на конкурентні позиції компанії, її } \\
\text { керівництво унеможливлює розробку та впровадження стратегії } \\
\text { існування та фрункціонування організації. }\end{array}$ \\
\hline $\begin{array}{l}\text { Інвестиційна } \\
\text { привабливість }\end{array}$ & $\begin{array}{l}\text { Оцінка інвестиційної привабливості компанії здійснюється шляхом } \\
\text { розрахунку господарського стану компанії та використовує } \\
\text { фрінансові показники. До складу цих показників входять: ліквідність, } \\
\text { майновий стан, ділова активність, фрінансова залежність, } \\
\text { рентабельність. }\end{array}$ \\
\hline
\end{tabular}

Джерело: доопрацьовано авторами на основі [3, с. 16-17]

Відповідно до розпорядження «Про схвалення Концепції розвитку цифрової економіки та суспільства України на 2018-2020 роки та затвердження плану заходів щодо іiї реалізації» Кабінет Міністрів України ухвалив 8 основних принципів цифровізації економіки України: доступність, цільове призначення, перетворення, розвиток, співпраця, стандартизація, довіра та безпека, комплексність [12], які $€$ основоположними для розвитку цифррової економіки. Аналіз процесів цифррової трансорормації відносин банків та інших суб'єктів орінансового ринку дає змогу дійти висновку, що у банків все ще $є$ конкурентні переваги, а альтернативні постачальники цифрових послуг тільки їх фрормують.

На даному етапі актуальності набуває «Monobank» - це український інтернет-банкінг, для роботи використовується банківська ліцензія АТ «Універсал Банк». Станом за 2020 рік кількість платіжних карток зросла в 1,7 разів порівняно з 2019 роком. В січні 2020 року кількість користувачів картки monobank становила 1,8 млн. осіб, а вже станом на грудень 2020 року - 3,1 млн. осіб [11]. Продукт передбачає обслуговування без відділень, майже всі послуги надаються за допомогою мобільного застосунку. Комунікація між клієнтом та банком відбувається за телефоном, електронною поштою або у месенджерах Telegram, Rakuten Viber, Facebook Messenger та iMessage.

ще один вдалий український продукт «Приват24», який був створений у 2001 році АТ КБ «ПриватБанк». «Приват24» - проєкт, що дав можливість клієнтам керувати своїми рахунками онлайн в режимі реального часу, виконувати регулярні платежі, переказ коштів тощо. ПриватБанк належить до найбільших розробників мобільних платіжних додатків в Україні [10].

На основі даних з Міністерства орінансів України стосовно народного рейтингу банків, який будується на підставі відгуків відвід- 
увачів «Мінфіну» про якість обслуговування в банках перше місце займає Monobank 3 рейтингом 26,9, в той час, як АТ КБ «ПриватБанк» займає дев'яте місце з рейтингом 17,4 [8].

Висока популярність безконтактних платіжних інструментів привела до суттєвого зростання безготівкових операцій із використанням безконтактних та токенізованих карток (за допомогою смарторонів та інших NFC-пристроїв). Понад половини від загальної кількості та суми безготівкових операцій у торговельних мережах (54\% за обома показниками) за дев'ять місяців 2020 року відбувалося безконтактно, тоді як рік тому - лише третина [9].

Удосконалення управління цифрровізацією банків полягає в імплементації концепції «цифрової ДНК» банку, яка базується на комплексній системі управління процесами цифровізації та передбачає:

1. Перегляд бізнес-моделі та операційної моделі банку - має на меті підвищення рівня продуктової цифрровізації задля покращення результатів діяльності банку.

2. Вибудовування екосистеми партнерських взаємовідносин з компаніями, що забезпечують створення нових цифрових інновацій.

3. Модернізацію взаємодії з клієнтами, що передбачає перехід до клієнтоорієнтованого підходу в процесі розробки послуг та зосередження уваги на комплексному обслуговуванні клієнтів, а не на продажі окремих продуктів.

4. Формування архітектури даних банку та всіх його підрозділів з метою забезпечення гнучкого та багатофрункціонального їх використання.

На даному етапі розвитку цифрової економіки НБУ та Міністерство цифрової трансорормації спільно працюють над цифрровізацією банківської системи України. Результат цієї співпраці - це доступні онлайн-послуги світового рівня, які відкривають нові можливості як для банків, так і для їхніх клієнтів [9].

Команда Міністерства цифрової трансформації України однією з перших у світі запустила послугу передачі (або шерингу) цисррових документів. Передача електронних паспортів у застосунку Дія (скорочено від «Держава і я») - це послуга, що дозволяє громадянам ідентифрікувати свою особистість у банку та надати свої документи у циорровому срорматі, щоб відкрити банківський рахунок, не виходячи з дому.

Послугу можна використовувати як на онлайн-ресурсах банку (мобільному застосунку чи сайті), так і у звичайному відділенні банку. Понад 25 млн. українців вже можуть користуватись послугами банків з допомогою цифрових документів. За перший тиждень роботи отримано близько 4000 заявок нових клієнтів на реєстрацію через «Дія». Банки зможуть оптимізувати свої процеси, скоротити бюрократичні процедури, впровадити сучасні послуги, підвищити конкурентоспроможність.

Важливою під час пандемії також $є$ мінімізація соціальних контактів, яку забезпечує впровадження онлайн-послуг. У подальших планах НБУ та Міністерства цифррової трансформації України діджиталізація інших фрінансових установ - страхових, кредитних компаній тощо [9].

Хоча Інтернет-банки стають все більш популярними у світі та в Україні через ряд їх переваг над традиційними, вони також мають ряд недоліків, основними серед яких є: висока вартість створення та впровадження спеціалізованих послуг та програм; значні витрати на розробку та впровадження надійного захисту від інтернет-шахраїв та кібервірусів; необхідність великих капіталовкладень на розвиток необанку; низький рівень грамотності в країні та світі, що погіршує технічні переваги необанкінгу перед традиційним банком; наявність недовіри щодо переходу до альтернативних платіжних систем тощо.

Саме тому для досягнення розвитку цифрровізації українських банків варто звернути увагу на основні складові управління сучасного цифррового банку, а саме:

1. Багатоканальний банкінг. Кожному каналу потрібен власний набір робочих процесів, вмісту, дизайну екрану та інших засобів підтримки. Робота повторюється багато разів, а кінцевий результат розподіляється по каналах, які не пов'язані між собою. Замість того, щоб створювати цифррові ділові срункції для кожного каналу, актуальності набуває розробка одного і розподіл по всіх каналах через центральний концентратор. Для цього необхідна центральна багатоканальна платсрорма цифрового банкінгу для організації взаємодії з клієнтами через будь-яку точку дотику.

2. Модульний банкінг. Завдяки модульній архітектурі банки можуть здійснювати інновації швидко і відповідно до потреб клієнтів. Модульна архітектура надає банку можливість виходити за рамки реагування на ринкові реалії та активно створювати їх спільно з клієнтом.

3. Відкритий банкіне. Банки повинні відкрити свої прикладні програмні інтерфейси. При правильному використанні це може допомогти їм вдосконалити свої продукти та послуги. Відкритий банкінг має декілька 
елементів: доступ до з'єднань; розподілена робота; одиничне виробництво; спільне значення; управління достатком.

4. Розумний банкінг. Ефрективна сегментація, націлювання та відстеження здійснюється шляхом збору даних з різних джерел та їх аналізу для створення ефрективних статистичних даних.

Кожен клієнт отримує товар або послугу, пристосовану до його індивідуальних потреб, через найбільш підходящий для них канал або канали відбору. Цей підхід керує задоволенням споживачів, пристосовуючи як товар, так і канал збуту до їхніх потреб у будь-який момент часу. Кожна із цих чотирьох складових $\epsilon$ фрундаментальним алгоритмом для успішного управління в цифровій економіці щодо банківської галузі майбутнього.

Висновки. Основним акцентом цисрової економіки $є$ застосування цифрових, комунікаційних та інфрормаційних технологій у віртуальному світі, що сприяє покращенню економіки країни та її інвестиційної привабливості. Поява «необанків» як нової фрорми банківської діяльності пов'язана із значним розвитком Інтернет-технологій та появою нового покоління споживачів, які активно викорис- товують смартфони у повсякденному житті та віддають перевагу тотальному дистанційному контролю власними фрінансами. Саме тому доцільна імплементація концепції «цифрової ДНК» банку, яка базується на комплексній системі управління процесами цифровізації, що передбачає: перегляд бізнес-моделі та операційної моделі банку, вибудовування екосистеми партнерських взаємовідносин, модернізацію взаємодії з клієнтами та формування архітектури даних банку.

В умовах активного розвитку діджиталізації сучасні клієнти в процесі оцінки фрінансової установи більше не порівнюють різні банки, вони порівнюють досвід. Хоча Інтернетбанки стають все більш популярними у світі та в Україні через ряд їх переваг над традиційними, вони також мають багато недоліків. Саме тому для досягнення розвитку цисровізації інших українських банків варто впровадити основні складові управління сучасного цифррового банку, а саме: багатоканальний банкінг, модульний банкінг, відкритий банкінг та розумний банкінг. Кожна із цих чотирьох складових $€$ фрундаментальним алгоритмом для успішного управління в цисрровій економіці щодо банківської галузі майбутнього.

\section{СПИСОК ВИКОРИСТАНИХ ДЖЕРЕЛ:}

1. Бухт Р., Хікс Р. Визначення, концепція та вимірювання цифррової економіки. Вісник міжнародних організацій. 2018. № 2. 149 c.

2. Войнаренко М.П., Скоробогата Л.В. Мережеві інструменти капіталізації інфоормаційно-інтелектуального потенціалу та інновацій. Вісник Хмельницького національного університету. 2015. № 3. С. 18-19.

3. Карчева Г.Т., Огородня Д.В., Опенько В.А. Цифрова економіка та її вплив на розвиток національної та міжнародної економіки. Фінансовий простір. 2017. № 3(27). С. 14-18.

4. Касич А.О., Підкуйко О.О., Коротенкова І.М. Роль державних банків у розвитку національної економіки. Інвестиції: практика та досвід. 2020. № 4. С. 36-40.

5. Кльоба Л.Г. Цифровізація - інноваційний напрям розвитку банків. Ефрективна економіка. 2018. № 12. URL: https://doi.org/10.32702/2307-2105-2018.12.84 (дата звернення: 17.04.2021).

6. Кузнєцова Л.В. Цифрова трансформація банківського бізнесу. Матеріали Міжнародної науково-практичної конфреренції. Львів, 2018. № 2. 73 с.

7. Лігоненко Л.О., Хріпко А.В., Доманський А.О. Зміст та механізм формування стратегії діджиталізації в бізнес-організаціях. Міжнародний науковий журнал «lнтернаука». 2018. № 22. URL: https://doi.org/10.25313/ 2520-2057-2018-22-4555 (дата звернення: 11.05.2021).

8. Міністерство фрінансів України. Народний рейтинг банків. URL: https://minfin.com.ua/ua/banks/top/ 2021-05-24 (дата звернення: 24.05.2021).

9. Національний Банк України. URL: https://bank.gov.ua (дата звернення: 16.04.2021).

10. Орріційний сайт АТ КБ «ПриватБанк». URL: https://privatbank.ua (дата звернення: 28.04.2021).

11. Офіційний сайт АT «Універсал Банк». URL: https://www.universalbank.com.ua (дата звернення: 23.04.2021).

12. Розпорядження Про схвалення Концепції розвитку цифрової економіки та суспільства України на 2018-2020 роки та затвердження плану заходів щодо іï реалізації. URL: https://zakon.rada.gov.ua/laws/ show/67-2018-\%D1\%80 (дата звернення: 02.05.2021).

13. Фіщук В. «Діджиталізація - це лише початок», 2018. URL: https://day.kyiv.ua/uk/article/ekonomika/ didzhytalizaciya-ce-lyshe-pochatok (дата звернення: 28.04.2021). 


\section{REFERENCES:}

1. Bukht R., Khiks R. (2018) Vyznachennya, koncepciya ta vymiryuvannya cyfrovoyi ekonomiky [Definition, concept and measurement of digital economy]. Visnyk mizhnarodnyx organizacij, no. 2, $149 \mathrm{p}$.

2. Vojnarenko M.P., Skorobogata L.V. (2015) Merezhevi instrumenty kapitalizaciyi informacijno-intelektual'nogo potencialu ta innovacij [Network tools for capitalization of information and intellectual potential and innovations]. Visnyk Xmelnytczkogo nacionalnogo universytetu, no. 3, pp. 18-19.

3. Karcheva G.T., Ogorodnya D.V., Openko V.A. (2017) Cyfrova ekonomika ta yiyi vplyv na rozvytok nacionalnoyi ta mizhnarodnoyi ekonomiky [Digital economy and its impact on the development of national and international economy]. Finansovyj prostir, no. 3(27), pp. 14-18.

4. Kasych A.O., Pidkuyko O.O., Korotenkova I.M. (2020). Rol' derzhavnyx bankiv u rozvytku nacionalnoyi ekonomiky [The role of state-owned banks in the development of the national economy]. Investyciyi: praktyka ta dosvid, no. 4 , pp. $36-40$.

5. Kloba L.G. (2018) Cyfrovizaciya - innovacijnyj napryam rozvytku bankiv [Digitalization is an innovative direction of banks' development]. Efektyvna ekonomika, no. 12. Available at: https://doi.org/10.32702/2307-2105-2018.12.84 (accessed 17 April 2021).

6. Kuznyeczova L.V. (2018) Cyfrova transformaciya bankivskogo biznesu [Digital transformation of the banking business]. Materialy Mizhnarodnoyi naukovo-praktychnoyi konferenciyi, Lviv, no. 2, p. 73.

7. Ligonenko L.O., Xripko A.V., Domanskyj A.O. (2018) Zmist ta mexanizm formuvannya strategiyi didzhytalizaciyi $v$ biznes-organizaciyax [Content and mechanism of digitalization strategy formation in business organizations]. Mizhnarodnyj naukovyj zhurnal «Internauka», no. 22. Available at: https://doi.org/10.25313/2520-2057-2018-22-4555 (accessed 11 May 2021).

8. Ministry of Finance of Ukraine. People's rating of banks. Available at: https://minfin.com.ua/ua/banks/ top/2021-05-24 (accessed 24 May 2021).

9. National Bank of Ukraine. Available at: https://bank.gov.ua (accessed 16 April 2021).

10. Official site of JSC CB "PrivatBank". Available at: https://privatbank.ua (accessed 28 April 2021).

11. Official site of JSC "Universal Bank". Available at: https://www.universalbank.com.ua (accessed 23 April 2021).

12. Order on approval of the Concept of development of the digital economy and society of Ukraine for 2018-2020 and approval of the action plan for its implementation. Available at: https://zakon.rada.gov.ua/laws/ show/67-2018-\%D1\%80 (accessed 02 May 2021).

13. Fishchuk V. (2018) «Didzhytalizaciya - ce lyshe pochatok» ["Digitalization is just the beginning"]. Available at: https://day.kyiv.ua/uk/article/ekonomika/didzhytalizaciya-ce-lyshe-pochatok (accessed 28 April 2021). 